\title{
ROMA HUKUKUNDA ŞARTIN ÖZEL BİR GÖRÜNÜMÜ: GLADYATÖR MÜSABAKALARINA BAĞLANAN HUKUKI SONUÇ
}

\author{
Duygu TAHAN ORHAN*
}

$\ddot{o} Z$

Gladyatör oyunlarl, şiddetin oldukça ön planda olduğu, ölüm ya da yaralanma ile sonuçlanması muhtemel müsabakalardır. Temelini dini törenlerden alan bu oyunlar, zaman içerisinde toplumsal eğlence anlayışının önemli bir parçası haline gelmiştir. Politik amaçlarla kullanılabileceği erken dönemde keşfedilen oyunlara hukukun müdahalesi de gecikmemiştir. Oyunların düzenlenmesi ve sinırlanmasi gibi hususlarda, muhtelif hukuki müdahaleler gerçekleşmiştir. Bunun yanı sıra, bireysel bir noktadan, ölene kurban vermekten ayrllp, organize faaliyetler haline gelen müsabakalar kapsamında, müsabakanın sonucu, müsabakayı düzenleyenler ile gladyatör okulları arasındaki hukuki ilişkinin tespiti açısından önem arz etmektedir. Bu kapsamda, müsabakaya katılan gladyatörlerin ölmesi veya ağır yaralanması, ya da yara almadan veya hafif yaralarla müsabakadan ayrlması, organizatörler ile lanista arasındaki hukuki ilişkiyi tespit eden unsuru teşkil etmektedir.

Anahtar Kelimeler: gladyatör, lanista, alım satım, locatio conductio, şart

\section{A SPECIFIC FORM OF CONDICIO UNDER ROMAN LAW: THE LEGAL RESULT ATTACHED TO THE GLADIATORIAL COMBATS}

\section{ABSTRACT}

Gladiatorial combats are games where violence is quite apparent and thus have a possible result of death or injuries. These games, originating from religious ceremonies, became an important part of social entertainment in time. To these games, which were found out to be appropriate to use for political reasons in early times, legal intervention was not late. A variety of legal interventions made about the organizations and limits of the games. Along with that, the result of the combat, which evolved from being a part of funerals to organized events, had a great importance regarding the relationship between the organizers and gladiator schools. In this context, the death, injuries or leaving the combat without any injuries was the factor determining the legal relationship between the lanista and the organizers.

Key Words: gladiator, lanista, emptio venditio, locatio conductio, condition

\footnotetext{
Dr., Ankara Barosu Avukat1. e-posta: duygutahan@gmail.com

DOI : 10.34246/ahbvuhfd.609103

Yayın Kuruluna Ulaştığı Tarih

:25/03/2019

Yayınlanmasının Uygun Görüldüğü Tarih: 03/07/2019
}

Ankara Hacı Bayram Veli Üniversitesi Hukuk Fakültesi Dergisi C. XXIII, Y. 2019, Sa. 3223 


\section{GİRIŞ}

Antik Roma'dan söz edildiğinde, bugün halen ilgi çeken hususlardan biri, gladyatör müsabakalarıdır. Günümüz popüler kültüründe dahi etkisi bu derece gözle görülebilir büyüklükteyken, iletişimin ve eğlence araçlarının bugüne kıyasla son derece sinırlı olduğu Roma toplumunda, gladyatör müsabakalarının uyandırdığı ilgiyi öngörmek güç olmayacaktır.

Roma eğlence anlayışının önemli bir unsurunu teşkil eden bu gösterilere hukukun müdahalesi kaçınılmaz olmuştur. Kimi suçluların gladyatör okullarına mahkum edilmesi ${ }^{1}$, gladyatör oyunlarının çeşitli nedenlerle sınırlandırılmas $1^{2}$ ya da bazı kişilerin müsabakalardan yasaklanması ${ }^{3}$, hukukun bu organizasyonlara müdahalesinin örneklerini teşkil eder.

Bunun ötesinde, gladyatörler temelde köledir ve kölelerin birbirleri ile fiziki mücadele içine girdiği bu tip oyunlarda, muhtemel sonuç taraflardan birinin hayatını kaybetmesi ya da en azından yaralanmasını içerir. Teorik olarak, kölenin eşya olduğu gözetildiğinde, eşyanın uğradığı zararlar dolayısıyla sorumluluğun doğacağı öngörülebilir. Fakat gladyatörler açısından böylesi bir durumda, farklı bir hukuki ilişkinin varlığı gözetilmelidir. Gladyatörlerin maruz kaldıkları yaralanma ve ölümler, gladyatör okulları ile organizatörler arasındaki hukuki ilişki çerçevesinde değerlendirilmiştir.

Çalışmamız kapsamında, bu doğrultuda, gladyatörlerin hukuki statüsü ve lanista ${ }^{4}$ ve organizatörlerin arasındaki hukuki ilişki ile, bu çerçevede ortaya çıkan hukuki sonuçlar değerlendirilecektir. ${ }^{5}$

BAUMAN, s. 122-123; BUCKLAND, s. 277, 404-405; "Servus poenae: Ölüme veya müebbet küreğe mahkum edilmek neticesinde hürriyet durumunu (status libertatis) kaybeden ve bu suretle köle durumuna düşen kimse.", UMUR, s. 198.

2 Ziyafet ve cenaze törenleri için yapılacak harcamaları kısıtlayan lex Cornelia de Sumptuaria gibi, BERGER, s. 550.

3 Yüksek toplumsal statüde bulunan kişilerin auctorati olarak müsabakalara katılmalarını engelleyen M.Ö. 46, 38 ve 22 tarihli emirnameler gibi, KYLE, (2007), s. 318.

4 Lanista, gladyatör okulu sahibine verilen isimdir, WACKE, s. 283.

5 Çalışmada kullanılan metinlerin incelenmesinde, Watson (IUSTINIANUS-1998), Birks/ McLeod (IUSTINIANUS 1987), Poste (POSTE), Hyamson (Ed.: HYAMSON) ve Umur'un (IUSTINIANUS -1955) çevirilerinden faydalanılmıştır. 


\section{GLADYATÖRLERINN HUKUKİ STATÜSÜ}

Din, Roma toplumunda pek çok kurumu etkilediği gibi, eğlence anlayış1 üzerinde de etkili olmuştur. Ataya tapmanın görüldüğü Roma'da, ev tanrıları büyük önem taşır ${ }^{6}$. Bu nedenle, cenaze törenleri, dikkatle şekillendirilen dini törenler olmuştur. $\mathrm{Bu}$ törenler kapsamında, ölünün ruhunu kurban kanıla teskin etmek ihtiyacı ve köle ve hayvanların ölülere mezarlarında da dünyada olduğu gibi hizmet edeceği düşüncesi ${ }^{7}$, Romalıları hayvan ya da ucuz köle kurban etmeye yönlendirmiştir. Zaman içerisinde, bu kurban etme törenleri, yerini, ucuz kölelerin birbiri ile fiziki müsabakaya girdiği gladyatör dövüşlerine bırakmıştır. Cenaze töreni ile ortaya çıktığı kabul gören gladyatör oyunları, Cumhuriyet Dönemi itibariyle, gündelik hayatın bir parçası olarak, eğlenceye yönelik organizasyonlara dönüşmüştür8.

Gladyatör müsabakalarının düzenlenmesi hayli maliyetlidir. Öncelikle, müsabakalara katılmak üzere, uygun kölelerin temin edilmesi gerekir. Müsabakaların henüz organizasyonu aşamasında, bu kölelerin önemli bir kısmının arenadan ölerek ya da ağır yaralanarak ayrılacağını öngörmek güç değildir. Esasında, gladyatör müsabakalarında ölüm, organizasyonda ulaşılabilecek eğlencenin en üst noktası olarak görülmektedir ${ }^{9}$. Ancak bütün bu yüksek maliyetlere rağmen, politik amaçlar doğrultusunda müsabakaların düzenlenmesi önem arz etmiştir. Hatta, bireysel adanmışliklar ile ortaya çıkan bu müsabakalar, politikacıların kalabalık halkı gösterişi ile etkilemek, güç sahibi olduğu izlenimini bırakmak, halkın desteğini arkasına almak ve sıradan bireyleri şiddet gösterileri ile oyalayarak sıkıntılarını unutturmak amaçlarıyla kullanılan politik araçlar haline gelmiştir ${ }^{10}$.

$\mathrm{Bu}$ işleyişin merkezinde yer alan aktörler, pek tabii ki gladyatörler olmuşlardır. Etraflarında gerçekleşen karmaşık politikalar bir yana, arenada ölümüne mücadele içinde bulunanlar gladyatörlerdir. Gladyatörler, onurlu bir şekilde ölüme giden savaşçılar olarak görülmektedir ${ }^{11}$. Ancak arenada bulundukları süre boyunca kendilerine saygı duyulsa da, esasında gladyatörler çok büyük oranda kölelerden ibarettir.

\footnotetext{
6 De COULANGES, s. 35 vd.

7 De COULANGES, s. 18-19.

8 UZUNASLAN, s. 19, 22.

9 EDWARDS, s. 46.

10 MEIJER, s. 15, 31.

11 MEIJER, s. 40, 41.
}

Ankara Hacı Bayram Veli Üniversitesi Hukuk Fakültesi Dergisi C. XXIII, Y. 2019, Sa. 3225 
Savaş esirleri, gladyatörlerin ilk örneklerini teşkil etmektedir ${ }^{12}$. M.S. I. yüzyıldan itibaren, savaş esirlerinin yanı sıra, kimi ağır suçların yaptırımı olarak da gladyatör okullarına mahkumiyete hükmedildiği görülmektedir. Gladyatör okullarına mahkûm olanlar, servus poenae ${ }^{13}$ olarak adlandırılırlar. Esasinda, nihayetinde "ölümüne" bir fiziki mücadeleye girilecek olsa da, bu, doğrudan doğruya verilecek bir idam cezasina klyasla çok daha arzu edilir bir cezadır. Nitekim, bir idam cezasının infazl, cezanın verildiği tarihten itibaren en geç bir yul içerisinde gerçekleşirken, gladyatör okuluna mahkumiyette, çok nadir de olsa, kişinin tekrar özgürlügünü kazanması ihtimali dahi mevcuttur ${ }^{14}$. Bu haliyle, ani ve kesin bir ölüm karşısında, yaşama ve hatta özgürlüğüne kavuşabilme ihtimalinin, en azından çok kişi açısından daha cazip olacă̆l açıktır.

Coll. 11.7. 4 (Ulp. lib. 8 de officio proconsulis): “...Est autem differentia inter eos qui ad ludum damnatur: nam ad gladium damnati confestim concumuntur uel certe intra annum debent consumi : hoc enim mandatis continetur. Enimuero qui in ludum damnatur, nun utique consumuntur sed etiam pilleari et rudem accipere possunt post interuallum, siquidem post quinquennium pilleari post triennum autem rudem induere eis permittitur."

Coll. 11.7. 4 (Ulp. lib. 8 de officio proconsulis): “...Ne var ki, kılıç cezasına mahkûm edilenler ile ludus'a mahkûm edilenler arasında fark vardır; ilk gruptakiler gecikmeksizin öldürülürler, ya da her halükarda bir yıl içerisinde öldürülmek zorundadırlar, ve bu talimat hükümde yer alır.

12 MEIJER, s. 40; FUTTRELL, s. 121; ANDERSON, s. 6; TEKIN, s. 258.

13 "Ölüme veya müebbet küreğe mahkûm edilmek neticesinde hürriyet durumunu (status libertatis) kaybeden ve bu suretle köle durumuna düşen kimse.", UMUR, 1983, s. 198; Servus poenae, mahkûm edildikleri cezanın kölesi olarak kabul edilirler, KARADENIZ ÇELEBİCAN, (2014), s. 133; BUCKLAND, s. 277, 404-405; Iustinianus'un Institutiones'inde, servus poenae olmak bir capitis demunito maxima hali olarak geçmektedir, Ius. Ins. 1. 16. 1.: "Maxima est capitis deminutio, cum aliquis simul et civitatem et libertatem amittit. quod accidit in his, qui servi poenae efficiuntur atrocitate sententiae...."; "Capitis demunito maxima, bir kişi özgürlügünü ve vatandaşlığını birlikte kaybettiğinde olur, çok ağır bir ceza olan servi poenae cezasına mahkûm edilmesinde olduğu gibi..."

14 MEIJER, s. 41; Umur, servus poenae'nin maliksiz olarak kabul edildiğini, bu nedenle azat edilmelerinin mümkün olmadığını ifade etmektedir, UMUR, s. 198. Ancak, zaten gladyatörler açısından söz konusu olan, efendisinin iradesi ile özgürlüğüne kavuşması anlamına gelen azatlanmak [TAHİROĞLU, s. 524] değil, kendi özgürlüklerini satın almaktır. 
Ancak ludus'a mahkûm edilenler mutlaka öldürülmek zorunda değildir; hatta belki, bir süre sonra, özgürlükleri iade edilebilir, ya da bir gladyatör olmak yükümlülüğünden kurtulabilirler; zira, üç yılın sona ermesi ile gladyatör oyunlarında yer almamalarına ilişkin izni alabilirlerken, beş yıl sonra, özgürlükleri iade edilebilir."

Savaş esirleri ve gladyatör okullarına mahkûm edilenlerin dışında, eski gladyatörlerden olan azatlıların da, bir auctoramentum'a taraf olarak, auctorati olarak gladyatör okullarına girdikleri görülmektedir ${ }^{15}$. Auctorati, bir ücret karş1lığında, kendini, tehlikeli faaliyetlerde bulunmak üzere bu tarz faaliyetlere yönelik iş yapan işletmelere bağlayan kişiler için kullanılan bir ifadedir. Umur, auctorati'lerin, özgürlüklerini korurken, ehliyetlerinin pek çok açıdan sınırlandığını ifade etmektedir ${ }^{16}$. Kyle ise, auctorati olarak, kazanç elde etmek amacıyla gladyatör okullarına kaydolan azatlı eski gladyatörlerin, özgürlüklerinden geçici olarak vazgeçtikleri kanaatindedir ${ }^{17}$. Nitekim, Kyle, auctoramentum'u, ücret, hizmet ya da müsabakaya çıkma şartlarının belirlendiği, auctorati'nin kendilerini gladyatör olarak kiraladıkları bir akit olarak nitelemektedir ${ }^{18}$.

Her ne kadar, muhtelif dönemlerde gladyatör müsabakalarına katılabilecek kişiler açısından çeşitli sınırlamalara gidilmiş olsa da, özgürlerin ve hatta toplumda yüksek statüde bulunan kişilerin dahi müsabakalara katıldığ 1 görülmektedir. Bir yeminin ifası, ya da savaş becerilerinin sergilenmesi, ya da yalnızca istek, özgür bir Roma vatandaşının gladyatör müsabakasına katılmasının nedeni olabilir ${ }^{19}$.

Özgür kişilerin müsabakalara katılabilmeleri için akitle kendilerini bir gladyatör okuluna bağlamaları zorunlu değildir. Münferit olarak müsabakalara çıkmaları mümkündür. Bununla birlikte, özgür Roma vatandaşları arasından da, gladyatör okullarına auctorati olarak kaydolanların varlığı bilinmektedir ${ }^{20}$. Bunun nedenini, her ne kadar hayati mücadeleye atılıyor olsalar da, güçlü sağl1k hizmetleri, iyi beslenme gibi göz ard1 edilemeyecek gladyatör

\footnotetext{
$15 \quad$ KYLE, (2007), s. 317.

16 UMUR, s. 26.

17 KYLE, (2007), s. 317.

18 KYLE, (1998), s. 87.

19 KYLE, (2007), s. 318-319.

20 KYLE, (2007), s. 318-319.
}

Ankara Hacı Bayram Veli Üniversitesi Hukuk Fakültesi Dergisi C. XXIII, Y. 2019, Sa. 3227 
hayat1 şartlarında aramak mümkündür ${ }^{21}$. Toplumun büyük kesiminin düşük standartlarda hayatını idame ettirmeye çalıştığ 1 düşünüldüğünde, bu okullara kayıt, cazip bir mesleğe dahil olmak anlamına gelmektedir. Yine, gladyatör olmanın getirdiği şöhret ve yaşadığı süre ile sınırlı olsa da gladyatörlere duyulan hayranlık, özgür Roma vatandaşlarının gladyatör okullarına kaydolması nedenlerinden bir kısmını teşkil eder. Müsabakalardan zafer ile ayrılan gladyatörler, yemek ve para ile ödüllendirilmektedir ${ }^{22}$. Bunun ötesinde, eski ve başarılı bir gladyatör olarak topluma geri dönmek, sıradan bir Romalının saygınlığını artıracak bir durum teşkil eder. Tüm bunlar birlikte değerlendirildiğinde, ortalama yaşam süresinin oldukça kısa olduğu Roma'da, hayat mücadelesi içindeki sıradan Romalılar için, gladyatör okullarına kaydolarak ücret karşılığında müsabakalara katılmak, iyi bir alternatif teşkil etmektedir ${ }^{23}$.

\section{GLADYATÖR MÜSABAKALARINA BAĞLANAN HUKUKİ SONUÇ}

Yukarıda da izah edildiği üzere, bir gladyatör müsabakasının olası sonucu, katılımcıların ölmesi ya da yaralanmasını içerir. Yine, yukarıda değinildiği üzere, gladyatör müsabakalarının katılımcıları, köleler ya da özgür Roma vatandaşları olabilir. Dolayısıyla, muhtemel yaralanma ya da ölümler içeren müsabaka sonuçlarını, köle gladyatörler ve özgür katılımcılar açısından ayrı ayrı değerlendirmek gerekir.

Roma hukuku kapsamında, kölelerin belirli açılardan insan oldukları gözetilmiş olmakla beraber, özü itibariyle köleler eşyadır ${ }^{24}$. Dolayısıyla kölelerin yaralanması ya da ölmesi, mala verilen zararlar kapsamında değerlendirilmeli; hukuka aykırıllı̆a etki eden özel durumlar, bu haksız fiil kapsamında incelenmelidir. Ne var ki, gladyatör köleler açısından durum farklıdır.

Gladyatör kölelerin uğradıkları zararlar değerlendirilirken, gladyatörlerin bağlı oldukları okullar ile, müsabakaları düzenleyen organizatörler arasındaki hukuki ilişki esas alınmıştır.

21 ANDERSON, s. 7; JONES, s. 275.

22 ANDERSON, s. 7.

23 ANDERSON, s. 7.

24 KARADENIZ ÇELEBİCAN, (2014), s. 135; köleler, ius civile'de, Klasik Hukuk Dönemi boyunca önem arz eden en temel ayrım çerçevesinde, res mancipi'ler arasında sayılmıştır, KARADENIZ ÇELEBICAN, (2015), s. 44-45. 
Gai. Ins. 3. 146.: "Item [quaeritur] si gladiatores ea lege tibi tradiderim, ut in singulos qui integri exierint pro sudore denarii $x x$ mihi darentur, in eos uero singulos qui occisi aut debilitati fuerint denarii mille quaeritur utrum emptio et uenditio an locatio et conductio contrahatur. et magis placuit eorum qui integri exierint locationem et conductionem contractam uideri, at eorum qui occisi aut debilitati sunt emptionem et uenditionem esse; idque ex accidentibus apparet, tamquamsub condicione facta quiusque uenditione an locatione. Iam enim non dubitatur, quin sub condicione res ueniri aut locari possint."

Gai. Ins. 3. 146.: "Eğer şu şartlarda bir grup gladyatör temin edilirse; yani, arenayı sağ salim terk eden her birinin performansı için 20 denarii ödenecektir ve ölen veya sakatlanan her biri için 1000 denarii ödenecektir, denirse, bunun bir locatio conductio mu yoksa alım satım mı olduğu hususu ihtilaflıdır; ancak hakim görüş, bunun yaralanmadan gelenler için bir locatio conductio, ölenler ya da malul olanlar hakkında bir alım satım akti olduğu görüşüdür: Akitler şarta bağlıdır, her bir gladyatör için şartlı bir satış ya da locatio conductio vardır, ki satım akti de locatio conductio da şarta bağlı olarak yapılabilir."

Roma hukuku kapsamında, günümüz hukuk düzenlerinde hizmet akdi, eser akdi ve kira akdi olarak düzenlenen akitler, locatio conductio çatıs1 altında, birlikte ifade edilmektedir ${ }^{25}$. Taraflardan birinin bir hizmetin ifasını, diğer tarafin ise bunun karşılığında ücret ödemeyi taahhüt etmesi, locatio conductio operae, yani hizmet akdini ifade $\operatorname{eder}^{26}$. Hizmet akdi çerçevesinde, operae için aranan ifa yükümlülüğü sportif faaliyetler açısından söz konusu değildir ${ }^{27}$. Dolaysıyla, metinde işaret edilen locatio conductio'nun, hizmet akdini ifade ettiği söylenemez. Locatio conductio operis, bir eserin meydana getirilmesi borcunun üstlenildiği, karşı tarafın da bunun karşılığında ücret ödeme borcu altına girdiği eser akdini ifade eder ${ }^{28}$. Bu nedenle, metinde işaret edilenin eser akdi olmadığı sonucuna ulaşmak da kolaydır.

Akdin taraflarından birinin ücret ödeme borcu karşısında, diğer tarafın bir eşyanın belirli süreyle kullanımını temin etmeyi taahhüt etmesi locatio conductio rei, yani kira akdini oluşturur ${ }^{29}$. Bu çerçevede yapmış olduğumuz

\footnotetext{
25 Du PLESSIS, s. 12; RADO, s. 133; ERDOĞMUŞ, s. 96.

26 RADO, s. 138; ERDOĞMUŞ, s. 101.

27 KARADENIZ, s. 42; SOMER, (2008), s. 53.

28 RADO, s. 133; ERDOĞMUŞ, s. 102.

29 RADO, s. 134; ERDOĞMUŞ, s. 96.
}

Ankara Hacı Bayram Veli Üniversitesi Hukuk Fakültesi Dergisi C. XXIII, Y. 2019, Sa. 3229 
değerlendirmeler kapsamında da açıkça anlaşılacağı üzere, metinde ele alınan locatio conductio, locatio conductio rei'ye işaret etmektedir. Kaynaklarda, kölenin hizmetlerinin kiralanması için "locatio conductio operarum servi" ifadesi de kullanılmaktadır. Bununla birlikte, kölenin işi kölenin semeresi niteliğindedir ve semere eşyadan bağımsız şekilde kiralanamaz. Dolayısıyla, kölenin hizmetinin köleden ayrı şekilde kiralanamayacağı sonucuna ulaşmak güç değildir. Açıklanan bu nedenlerle, her halükarda kira akdinin konusunu bizatihi eşya olarak kölenin kendisi teşkil etmektedir ${ }^{30}$.

Görüleceği üzere, gladyatör müsabakaları sonucunda meydana gelecek zararlar, akdin niteliğini belirleyecek bir şart olarak değerlendirilmiştir. Buna ilişkin tartışma, gladyatör okulu ile organizatör arasındaki hukuki ilişkinin kira akdi mi yoksa alım satım akdi mi olduğu üzerinde şekillenmektedir. Gaius, metin kapsamında yer verilen akdin şarta bağlı kurulduğuna işaret eder. $\mathrm{Bu}$ bağlamda, müsabakadan zarar görmeden ayrılan gladyatörler ile, yaralanan ya da ölenler arasında bir ayrıma gitmiştir. Bu ayrım çerçevesinde, müsabakadan zarar almadan ayrılan gladyatörler açısından kira akdi; yaralanan ya da ölen gladyatörler açısından ise alım satım akdi söz konusu olacaktır. Buradan hareketle, müsabaka sona erene kadar, gladyatörlerin fiziki durumlarında bir değişiklik meydana gelmediği gözetilerek, bir locatio conductio'ya konu edildikleri sonucuna varmak mümkündür. Müsabaka sonucunda ise, zarar görmeyen gladyatörler değerlendirildiğinde, bozucu şart gerçekleşmemiş olacaktır. Dolayısıyla, zarar görmeden ayrılan gladyatörler açısından locatio conductio varlığını korur. Ölen ya da ağır şekilde yaralanan gladyatörleri ele aldığımızda ise, locatio conductio açısından bozucu şartın; alım satım akdi açısından ise kurucu şartın gerçekleşmesi söz konusu olur. Dolayısıyla, artık bu gladyatörler, locatio conductio'nun değil, alım satım akdinin konusunu teşkil ederler.

$\mathrm{Bu}$ ikinci ihtimal kapsamında, organizatör, gladyatörlerin arenada yaralanması ya da ölmesi riskini üstlenmiştir. Bir başka ifade ile, lanista ve organizatör arasındaki akit, bu doğrultuda şarta bağlanmıştır ${ }^{31}$. Şu halde, bir gladyatörün müsabakada ölmesi halinde, ölü bir gladyatörün alım satım akdine konu edildiği sonucuna varmak gerekir. Peki bu durum, borcun konusunun imkansız olamayacağı ilkesine aykırılık teşkil eder nitelikte midir? Wacke, bunun borcun konusunun imkansız olamayacağı ilkesine aykırılık teşkil

\footnotetext{
30 KARADENIZ, s. 48-50.

31 WACKE, s. 284.
} 
etmediği kanaatindedir; zira, organizatörün akit ile amaçladığı, hayatta kalan gladyatörlerin satın alınması değildir. Bir başka ifade ile, organizatörün lanista ile yapmış olduğu akitten doğan alacak hakkı sağ kalan gladyatörlere ilişkin değildir ${ }^{32}$. Gerçekten de, organizatör "eğer ölürse ya da maluliyet derecesinde yaralanırsa köleyi satın alacağı” şartı ile akde taraf olmaktadır.

$\mathrm{Bu}$ şartın, organizatörün tamamen aleyhine bir şart olduğunu söylemek son derece kolaydır. Nihayetinde, organizatör, hiçbir amaca yönelik kullanamayacağı, ekonomik bir değer taşımayan, ölü ya da ağır yaralı köleleri satın almaktadır. Ancak bu şartın varlığını açıklamak da aynı ölçüde kolaydır. Roma'da, gösteriler, önemli siyasi propaganda araçlarıdır. Gösterişli oyunlar düzenleyen politikacılar, bu oyunları bir üst makama gelmekte önemli bir araç olarak kullanırlar ${ }^{33}$. Oyunları büyük oranda kendi bütçelerinden karşılayan magistra'lar, organizasyon konusundaki becerilerini sergilemekle kalmayıp, muhtemel ekonomik sıkıntılarda yardıma koşacak cömert devlet görevlileri oldukları yönünde önemli bir mesaj verme şansını da elde etmiş olurlar ${ }^{34}$. Gracchus'un arenaya inşa ettirilen ve para karşıllı̆ı kiralanacak olan özel izleme tribünlerini şahsen ortadan kaldırtarak, tribunus plebis'lik makamına giden yolculuğunda haklın desteğini arkasına almasi ${ }^{35}$ ya da gladyatör müsabakalarına bilet sağlanmasının seçimlere hile karıştırmanın önlenmesi çerçevesinde yasaklanması ${ }^{36}$ gibi gerçekler gözetilirse, siyasi çıkarların bununla da sınırlı kalmadığı anlaşılacaktır. Özet bir ifade ile, müsabakaların devam etmesi, satın alınan kölenin sağ ve sağlıklı olmasından çok daha fazla organizatörün menfaatine hizmet eder. Dolayısıyla, esasında, organizatör, son derece aleyhine görünen bir şartı akde dahil ederek, bütün durumu lehine çevirmektedir. Gladyatörlerin ölmesi, organizatörün üstlendiği ve hatta desteklediği bir risktir.

Wacke'nin bu metne ilişkin ele aldığ diğer bir husus, hasarın alıcıya ait olduğu kuralıdır. Wacke, şarta bağlı alım satım akitlerinde, periculum emptoris est kuralının uygulanmayacağını ifade etmiş, devamla, Gaius'a ait metinde yer alan şartın, şarta bağlı bir akit söz konusu olmasaydı uygulama

\footnotetext{
32 WACKE, s. 284.

33 MAHONEY, s. 71; GÜRTEN, (2016), s. 144, dn. 739; TÜRKOĞLU, s. 255; SOMER, (2017), s. 47, 48; ANDERSON, s. 6; KYLE, (2007), s. 251-252.

34 FUTRELL, s. 3.

35 UZUNASLAN, s. 23.

36 MEIJER, s. 72, dn. 98; GÜRTEN, (2017), s. 71.
} 
alanı bulacak olan kuralı karşılamak üzere taraflarca uygulamaya konulduğunu belirtmiştir. Bir başka ifade ile, taraflar, akdin şarta bağlı olması dolayısı ile, uygulanamayacak olan hasarın alıcıya ait olması kuralına, aralarında yaptıkları anlaşma ile uygulama alanı yaratmaktadırlar ${ }^{37}$. Esasında bu düşüncenin teorik kurgusunu devam ettirmek için, bir bütün olarak şu değerlendirmenin yapılması gerekir: Lanista ile organizatör, özünde hiçbir şartın söz konusu olmadığı bir alım satım akdi gerçekleştirirlerse, ölen gladyatörler dolayısıyla ortaya çıkan hasar alıcı olan organizatörün üzerine kalacaktır. Buraya kadar, metinde amaçlanan sonuca ulaşılır. Fakat ölmeyenler açısından durum nasıl değerlendirilebilir? Akdin doğrudan doğruya bir alım satım akdi olduğundan söz edebilmemiz için, "Her bir gladyatör için X Sesters ödenecektir" kurgusunun yapılmış olması gerekir. Şu durumda, ölmeyen gladyatörler de alım satım akdine konu edilmiş olur ki metinden bunun amaçlanmadığı, ya da sistemin bu şekilde kurgulanmadığ1 görülmektedir. Akdin, daha olas1 bir şekilde, locatio conductio rei olarak gerçekleştirildiği varsayımında ise, hasara katlanması gereken kişi kiraya veren, yani lanista olacaktır ki, bu da metin çerçevesinde arzu edilmediği açıkça görülen bir husustur. Ancak Wacke, şarta yüklediği bu işlevden hareketle, organizatörün esasında yaralanan ya da ölen gladyatörleri satın almak niyetiyle hareket etmediğini, yalnızca riski üstlendiğini ifade etmektedir. Nitekim, yaralanan kölelerin tedavisi ve ölen kölelerin defni işlemleri, lanista' nın sorumluluğundadır. Dolayısıyla, esasında, burada, Romalı hukukçularca, kira ve alım satım akdi arasında şarta bağlı bir akit geliştirerek, değerli gladyatörlerin zarar görmesinden kaynaklanacak kayıp ve masraflar karşısında, organizatörün riski üstlendiği bir teminat ile, bir çeşit sigorta akdine benzer sonuçlara ulaşıldığı görülmektedir ${ }^{38}$.

Yukarıda izah edildiği üzere, özgür Roma vatandaşlarının, hatta zaman zaman toplumda yüksek statüde bulunan kimselerin de gladyatör müsabakalarına katılmaları mümkündür. Müsabakalara katılan özgür Roma vatandaşları açısından yapılacak değerlendirme, elbette ki köleler için yapılan değerlendirmeden farklı olacaktır. Bu durumda, ilk olarak, metinde yer verilen locatio conductio teriminden hareket edilebilir. Locatio conductio'ların, kapsamında, kira, hizmet ve eser akitlerinin var olduğu gözetilerek, özgür Roma vatandaşları açısından hizmet akdinin söz konusu olduğu düşünülebilir.

37 WACKE, s. 285.

38 WACKE, s. 285. Benzer şekilde Kyle, bu durumu, doğrudan, gladyatörlerin sahiplerinin, değerli gladyatörlerinin kaybına karşı kullandıkları bir güvence politikası olarak nitelendirmektedir, KYLE, (2007), s. 317. 
Ne var ki, yukarıda da ifade edildiği üzere, sportif faaliyetler, açık bir şekilde hizmet akdinin kapsamı dışında kalmaktadır ${ }^{39}$. Bunun yanı sıra, metinde alım satım akdinin de değerlendirildiği gözetildiğinde, özgür Roma vatandaşları açısından metinde yer alan açıklamanın yetersiz kaldığ 1 görülmektedir. Ayıca, metinde akde taraf olan kişi, müsabakaya katılan gladyatör değil, gladyatörlerin teminini sağlayan lanista'dır.

İkinci ve daha tutarlı ihtimal, özgür Roma vatandaşlarının gladyatör müsabakalarına katılmaları söz konusu olabilse bile, bu durumun onları tüm unsurları ile "gladyatör" sıfatı altına sokmayacağının düşünülmesidir. Bu durumda, gladyatör müsabakalarına bağlanan sonuçların değerlendirildiği Gaius'a ait metin yerine, diğer sportif faaliyetler açısından günümüzde yansımasını rıza çatısı altında kabul edilen risk olarak gördüğümüz, volenti non fit iniuria'nın değerlendirildiği metinlere gidilmesi uygun olacaktır. $\mathrm{Bu}$ kapsamda, muhtemel zararları öngörerek bu gibi müsabakalara katılan özgür kimselerin, bu müsabakalar kapsamında uğradıkları zararların tazminini talep etmeleri mümkün olmayacaktır; zira rızanın olduğu yerde, hukuka aykırılıktan söz edilemez ${ }^{40}$.

Auctorati'lerin özgürlük durumu hakkında doktrinde görüş birliği bulunmamaktadır. Umur, auctorati olarak hizmetlerini tehlikeli faaliyetlere sunan kimselerin, ehliyetlerinde belirli k1sitlamalar olmakla beraber, özgürlüklerini yitirmeyecekleri kanaatindedir ${ }^{41}$. $\mathrm{Bu}$ görüşten hareket edildiğinde, auctorati olarak gladyatör oyunlarına kendi hizmetlerini bir akitle bağlayan kişiler açısından, yukarıda özgür Roma vatandaşlarının katıldığı müsabakaların sonuçlarının geçerli olacağını söylemek gerekir. Bununla birlikte, bu kişiler açısından, yine lanista ile organizatör arasındaki bir hukuki ilişkiden söz edilmesinin gerekeceği kanaatindeyiz. Nihayetinde, lanista'nın bünyesinde yer alan ve emeklerini bu işe özgüleyen katılımcılar söz konusudur. Ancak bu durumu izah etmek, kölelerin durumunu izah etmek kadar kolay değildir. Bu noktada, Kyle'ın açılamaları bizi daha tutarlı bir sonuca ulaştıracaktır. Kyle, auctorati olarak gladyatör okullarına kaydolanların, geçici süreyle özgürlüklerini kaybedeceğini ifade etmektedir ${ }^{42}$.

39 KARADENIZ, s. 42; SOMER, (2008), s. 53.

$40 \quad$ D. 47. 10. 1. 5. (Ulp. lib. 56 ad. edictum): “... quia nulla iniuria est, quae in volentem fiat.” D. 47. 10. 1. 5. (Ulp. lib. 56 ad. edictum): “... zarara uğrayanın rızasının olduğu yerde, iniuria yoktur.", GÜNEŞ PESCHKE, s. 874.

41 UMUR, s. 26.

42 KYLE, (2007), s. 317.

Ankara Hacı Bayram Veli Üniversitesi Hukuk Fakültesi Dergisi C. XXIII, Y. 2019, Sa. 3233 
Kyle'ın bu açılamasından hareket ettiğimizde, auctorati olarak gladyatör müsabakalarına katılanlar hakkında yukarıda yer alan Gaius'a ait metnin uygulanacağını söylemek gerekir.

\section{SONUÇ}

Gladyatörler, yaşamları boyunca saygı duyulan, ölmekten korkmayan, popüler, güçlü ve cesur savaşçlar olarak bilinseler de, esasında, temelde, politikacıların halkın desteğini almak ya da halkı manipüle etmek için kullandıkları, birbirleri ile ölümüne mücadele içine soktukları kölelerdir. Bu ölüm kalım mücadelesi, çoklukla katılımcılardan birinin ölümü ya da ağır derecede yaralanması ile sonuçlanmaktadır. Dolayısıyla, özünde bir eşyanın zarar görmesi olarak niteleyebileceğimiz bu husus, hukukçular tarafından incelenerek, zarar ile sonuçlanan müsabakalara ilişkin bir değerlendirme yapılmıştır.

Köle olan gladyatörler açısından bu değerlendirme Gaius tarafından açık bir şekilde yapılmıştır. Gladyatör okulları, lanista' lar, ile müsabakaları düzenleyenler arasındaki hukuki ilişki, müsabakadan önemli yaralar almadan ayrılan gladyatörler açısından kira akdi, ölen ya da maluliyet derecesinde yaralanan gladyatörler açısından ise alım satım akdi olarak tespit edilmiştir. Gladyatörün müsabakadan ne şekilde ayrıldığı, akdin niteliğini tespit edecek şart olarak lanista ile organizatör arasındaki hukuki ilişkiye eklenmektedir.

Özgür Roma vatandaşlarının katıldığı gladyatör müsabakalarının, köleler için öngörülen hukuki sonuçlar çerçevesinde değerlendirilmesi mümkün değildir. Dolayısıyla, özgür Roma vatandaşları açısından, diğer sportif unsurlar içeren faaliyetler ve bunların ötesinde kalan çok geniş bir yelpazede uygulama alanı bulan volenti non fit iniuria ilkesi söz konusu olacaktır.

\section{KAYNAKÇA}

ANDERSON, Jack: The Legality of Boxing - A Punch Drunk Love, 1. Bask1, Birkbeck Law Press, Oxon Oxon, 2007.

BAUMAN, Richard A.: Human Rights In Ancient Rome, Yeniden basim, 
Routledge, Londra, 2000.

BERGER, Adolf: Encyclopedic Dictionary of Roman Law, The American Philosophical Society, Philedelphia, 1991.

BUCKLAND, W. W.: Roman Law of Slavery, The Condition of the Slave in Private Law From Augustus to Justinian, Cambridge University Press, Cambridge, 1908.

De COUlangeS, Fustel: Antik Site, Yunan'dan Roma'ya Kadar Tapınma, Hukuk ve Kurumlar, (Çev.: KILINÇ, İ.), Birinci Baskı, Epos Yayınları, Ankara, 2011.

Du PLESSIS, Paul J: Letting and Hiring in Roman Legal Thought, 27 BCE-284 CE, 1. Bask1, Brill, Boston, 2012.

EDWARDS, Catherine: Death in Ancient Rome, Yale University Press, New Heaven ve Londra, 2007.

ERDOĞMUŞ, Belgin: Roma Borçlar Hukuku Dersleri, 2. Bask1, Der Yayınları, İstanbul, 2012.

FUTTRELL, Alison: The Roman Games Historical Sources in Translation, 1. Bask1, Blackwell Publishing, Malden, 2006.

GÜNEŞ PESCHKE, Seldağ: "The Reflection of Volenti Non Fit Iniuria in Personality Rights in Modern Laws", Principios Generales Del Derecho. Antecedentes Históricos Y Horizonte Actual, (Koordinatör: Fernando Reinoso Barbero), 1. Bask1, Thomson Reuters Aranzadi, Madrid, 2014, s. 869-876.

GÜRTEN, Kadir: Roma Hukuku'nda Crimen Kavramı, 1. Baskı, Seçkin, Ankara, 2016.

GÜRTEN, Kadir: "Roma'da Devlete Karşı İşlenen Bazı Suçlar ve Cezaları", Ankara Barosu Dergisi, Y1l: 75, S: 2017/3, Ankara, 2017, s. 53-79.

IUSTINIANUS: Institutiones, (Çeviren: UMUR, Ziya), İstanbul Üniversitesi Yayınları, İstanbul, 1955.

IUSTINIANUS: Justinian's Institutiones, (Çeviri ve Giriş: BIRKS, Peter ve McLEOD, Grant, Latince Metin: KRUEGER, Paul), 1. Bask1, Cornell University Press, New York, 1987. 
Roma Hukukunda Şartın Özel Bir Görünümü: Gladyatör Müsabakalarına...

IUSTINIANUS: The Digest of Justinian, (Çeviri Düzenlemesi, WATSON, Alan), Gözden Geçirilmiş Baskı, University of Pennsylvania Press, Cilt 4, Pennsylvania, 1998.

JONES, Peter: Geldim, Gördüm, Yendim, Romalılar Hakkında Bilmek İsteyeceğiniz Her Şey, (Çev.: F. Sezer), 1. Baskı, Say Yayınları, İstanbul, 2016.

KARADENIZ, Özcan: Iustinianus Zamanına Kadar Roma'da İş İlişsileri, Ankara Üniversitesi Yayınları, Sevinç Matbaası, Ankara, 1976.

KARADENİZ ÇELEBİCAN, Özcan: Roma Eşya Hukuku, 5. Baskı, Turhan Kitabevi, Ankara, 2015.

KARADENIZ ÇELEBİCAN, Özcan: Roma Hukuku, Tarihi-KaynaklarGenel Kavramlar-Kişiler Hukuku-Hakların Korunması, 17. Baskı, Turhan Kitabevi, Ankara, 2014.

KYLE, Donald G.: Spectacles of Death in Ancient Rome, 1. Bask1, Routledge, New York, 1998.

KYLE, Donald G.: Sport and Spectacle in the Ancient Roman World, 1. Baskı, Blackwell Publishing, Malden, 2007.

MAHONEY, Anne: Roman Sports and Spectacles, A Sourcebook, 1. Bask1, Focus Publishing, Malden, 2001.

MEIJER, Fik: Gladyatörler, Tarihin En Ölümcül Sporu, (Çev.: D. GÜNENÇ), 1. Baskı, Homer Kitabevi, İstanbul, 2008.

POSTE, Edward: Gai Instıtviones or Institutes of Roman Law by Gaius, Edward Poste M.A. Çevirisi ve Yorumu ile, E. A. Whittuck, M.A., B.C.L., Gözden Geçirilmiş ve Genişletilmiş 4. Baskı, A.H.J. Greenidge'in Tarihi Girişi İle, Oxford, 1904.

RADO, Türkan: Roma Hukuku Dersleri, Borçlar Hukuku, Filiz Kitabevi, İstanbul, 2006.

SOMER, Pervin: Roma Hukukunda Mala Verilen Zarar, 1. Bask1, Derin Yayınları, İstanbul, 2008.

SOMER, Pervin: "Roma İmparatorluğunda Seçim Yolsuzlukları ve Ambitus", Marmara Üniversitesi Hukuk Fakültesi Hukuk Araştırmaları Dergisi, Prof. Dr. Bülent Tahiroğlu'na Armağan, Y1l: 2017, Cilt: 23, 
Say1: 3, s. 33-54.

TAHIROĞLU, Bülent: "Roma Hukukunda Azad Etmenin Tahditleri", İstanbul Üniversitesi Hukuk Fakültesi Mecmuası, Y11: 1973, Cilt: 38, Say1: 1-4, s. 521-546.

TEKIN, Oğuz: Eski Yunan ve Roma Tarihine Giriş, 9. Bask1, İletişim Yayınları, İstanbul, 2015.

TÜRKOĞLU, Gökçe: "Roma Cumhuriyet ve İlk İmparatorluk Dönemlerinin İdari Yapısı”, Dokuz Eylül Üniversitesi Hukuk Fakültesi Dergisi, Yı1: 2009, Cilt: 11, Say1: 2, s. 251-289.

UMUR, Ziya: Roma Hukuku Lügatı, İstanbul Üniversitesi Hukuk Fakültesi Yayınları, Fakülteler Matbaası, İstanbul, 1983.

UZUNASLAN, Abdurrahman: “Antik Roma'da Gladyatör Oyunları", Süleyman Demirel Üniversitesi Fen-Edebiyat Fakültesi Sosyal Bilimler Dergisi, Y11: 2005, Say1: 12, s. 15-58.

WACKE, Andreas: "Accidents in Sport and Games in Roman and Modern German Law", Tydskrif Vir Hedendaagse Romeins-Hollandse Reg (Journal of Contemporary Roman-Dutch Law), Y11: 1979, Cilt: 42, Say1: 1, Butterworths, s. 273-287.

\section{Elektronik Kaynaklar}

Mosaicarum et Romanarum legum Collatio, (Ed.: M. Hyamson), Londra, 1913, https://archive.org/details/cu31924029129876 (Son erişim tarihi: 17.12.2018). 
